\title{
New Town, New Townspeople: Transforming Gatchina in the 1790 s
}

\author{
Alison K. Smith \\ The University of Toronto \\ alison.smith@utoronto.ca
}

\begin{abstract}
:
On November 11, 1796, only five days after the death of Catherine II, her son and successor Paul released a decree naming two of his villages, Pavlovsk and Gatchina, towns. In an odd way, given their fraught relationship, this act echoed his mother's past practice. She founded several hundred new towns to serve as new administrative centers for her newly formed provinces. Both of their actions recognized that there were two important ways to define a settlement as a town. Towns needed institutions and a physical plan appropriate to their status, and they also needed proper townspeople. This article examines the process by which Gatchina, the village, was transformed into Gatchina, the town. In particular, it focuses on the establishment there of new merchant and meshchanin corporations, and of a town ratusha to oversee their management. Many of the new town's new townspeople came from elsewhere to register there; as a result, they not only built up the town in numbers but also proved to be a source of public disorder as their presence was gradually regularized. This transformation thus shows both an effort at social organization and engineering and also the limits of those efforts when faced with individual desires.
\end{abstract}

\section{Keywords:}

Paul I, Emperor, Gatchina, towns, administration, social organization

When the new Emperor Paul proclaimed his village of Gatchina to be a town within days of taking the throne in 1796, he was probably thinking above all of his own glory. In 1783, his mother, Catherine II, had granted him the village as part of a generous gift in honor of the birth of her granddaughter Aleksandra-the gift included the palace of Gatchina as well as a dozen or so small and medium-sized villages in the area. ${ }^{1}$ Paul made the palace at Gatchina one of his principle residences, and began to develop the area in many ways. Most famously, he tried to make it a secure refuge against potential attack from St. Petersburgthis vision of Gatchina emphasized Paul's own personality, particularly his obsession with military things. As one visitor at the time put it, "entering into Gatchina seemed like entering into Prussian dominion." ${ }^{2}$ At the same time, Paul also sought to make Gatchina and its larger estate into a prosperous economic concern inhabited by hardworking, productive people (building a mill, founding a Lutheran church and a hospital, hiring a

\footnotetext{
${ }^{1}$ Polnoe sobranie zakonov Rossiiskoi Imperii: Pervoe sobranie, 45 vols. (St. Petersburg: Tipografiia II Otdeleniia Sobstvennoi Ego Imperatorskogo Velichestva Kantseliariia, 1830) (henceforth PSZ), vol. 21, no. 15808 (August 6, 1783); Stoletie gorod Gatchiny 1796 11/XI 1896 g., ed. S. Rozhdestvenskii (Gatchina: Gatchinskoe dvortsovoe upravlenie, 1896), 5 .

${ }^{2}$ A. S. Pishchevich, Zhizn' A. S. Pishchevicha, im samim opisannaia, 1764-1805 (Moscow: O-vo istorii i drevnostei ros. pri Mosk. un-te, 1885), 216. Even a visiting German princess agreed with the characterization of Gatchina as particularly "Prussian": "Pis'ma germanskoi printsessy o russkom dvore," Russkii arkhiv 7, no. 7 (1869): 1090-1102, here 1102.
} 
Swiss "cheese master" to produce cheese). ${ }^{3}$ Making the village of Gatchina into a town could be read as the crowning act of these efforts, in particular. Towns were the height of human civilization, in principle, at least-and as someone had recently written, "beginning in antiquity shrouded in darkness, we meet everywhere the memory of the founders of towns, exalted on a par with the memory of Lawgivers, and we see that heroes, celebrated for their victories, have endeavored through founding towns to give their names immortality." 4 What better way to celebrate his new reign than to turn the village next to his favorite palace into a town? ${ }^{5}$

Of course, the irony of this choice is that the author of those lines extolling the virtues of towns and town-builders was his detested mother. The text come from her Charter to the Towns, in which she laid out new governing principles for the Empire's urban (or not so urban) spaces, something made necessary in part by her own achievements in town creation. In fact, she went on to add, in her twenty-three years on the throne she had already founded 216 new towns, acts that made her among the most "exalted" of historical actors. Founding these towns was clearly important to her; she later listed "towns constructed" among her achievements, alongside "treaties concluded," "victories," and "edicts for improving the life of the people."

Not only did Paul's action echo Catherine's own view of the worth of founding towns but also he borrowed the process of making Gatchina the village into Gatchina the town from her past actions. Beginning in the 1770s, Catherine had in a series of decrees set up the mechanism whereby pre-existing villages became, legally, towns. These decrees focused both on the physical attributes of what made a town a town and also on what made a townsperson a townsperson. ${ }^{7}$ This second question was particularly important because Catherine's reign also saw a refinement of the legislation regarding soslovie, or social estate. Catherine's various decrees laid out clear paths for how individuals might change their soslovie and also emphasized that every subject of the Russian Empire ought to have a proper place denoted by soslovie status. ${ }^{8}$

As a result, when Paul created Gatchina as a town in part by drawing on these earlier decrees, he was engaging in two ways of defining what made a town a town. The first had to do with its physical plan. In this case, Paul was putting the final touches on a process he had been developing during his longer ownership of the area: economically developing the

\footnotetext{
${ }^{3}$ L. V. Ruzov and Iu. N. Iablochkin, Gatchina. Istoricheskii ocherk (Leningrad: Lenizdat, 1959), 14-17; Stoletie, 8-13.

${ }^{4}$ PSZ vol. 22, no. 16188 (April 21, 1785).

${ }^{5}$ Paul took this action less than a week after his accession to the throne. His accession was announced in a manifesto on November 6, 1796 (PSZ vol. 24, no.17530). The tenth ukase of his new reign made Gatchina a town, on November 11 (no. 17539). The following day, another ukase decreed Pavlovsk, the village next to his other significant palace, a town, as well (no. 17540).

${ }^{6}$ The Memoirs of Catherine the Great, ed. Dominique Maroger, trans. Moura Budberg (London: Hamish Hamilton, 1955), 371.

${ }^{7}$ On the culminating Charter to the Towns, see David Griffiths and George E. Munro, eds., Catherine II's Charters of 1785 to the Nobility and the Towns (Salt Lake City: C. Schlacks, 1991), and in particular Griffiths' introduction, "Of Estates, Charters, and Constitutions."

${ }^{8}$ Alison K. Smith, For the Common Good and Their Own Well-Being: Social Estates in Imperial Russia (New York, NY: Oxford University Press, 2014), chapter 3.
} 
nearest village to the palace to make it a proper showcase for his good governance and administration. The second had to do with its population. Here, he in some ways finished off a process of moving people into the area, but also began a clear new phase in its development as newly created local merchant and townspeople societies could now draw new members to the town and region. Looking at this change also highlights a third issue less recognized in Catherine's plans for new towns: the imperial nature of the tsarist state. In particular, looking at Gatchina and its history makes it impossible to forget that St. Petersburg was a metropole located in an imperial periphery. The larger peasant population around Gatchina were not Russians but Finns. Gatchina the town became a center of Russianness within that larger Finnish environment.

Hundreds of new towns were established across the Russian Empire during the eighteenth century. A few were established to secure the Empire's territorial expansion; these were often forts given town status and then opened to further development. A few represented the recognition of particular economic interests. Most, however, were established above all as administrative centers. These were established (and occasionally disestablished) at what probably seemed to their inhabitants as the whim of the monarch, a whim that subjected them to new regulations without regard to their normal way of life. This history has led many historians to debate whether Russian towns were ever truly towns, because it had the potential to create a situation in which both settlements and people often poorly fit the way the state saw them. ${ }^{9}$ And yet the labels of town or village mattered, and had real consequence for those who lived in them, just as personal labels did, as well. ${ }^{10}$

The initial grand moment of establishing new towns slightly predated Catherine's Guberniia reform of 1775. In 1770, she gave the Senate a decree transforming four rural settlements in Novgorod province (Vyshnii Volochek, Borovichi, Valdai, and Ostashevskaia sloboda) into towns. The decree was short. The towns were to be established "on the basis of other Russian towns," but why these new towns were needed and exactly what those bases were was at this point still unclear." Three years later, a second, slightly longer decree, hinted

\footnotetext{
${ }^{9}$ B. N. Mironov, Russkii gorod v 1740-186oe gody (Leningrad: Nauka, 1990), 15-19, discusses different ways of distinguishing between "rural" and "urban" settlements, and some of the ways that Russian settlements complicate that distinction. He further developed this question in Boris Mironov and Wladimir Berelowitch, "Les Villes de Russie Entre l'Occident et l'Orient (1750-1850)," Annales: Histoire, Sciences Sociales 46, no. 3 (June 1991): 705-33.

${ }^{10}$ Other approaches to the history of towns in eighteenth century Russia have sought to look above all at what was there, rather than what was not there in contrast to western towns. See, among many other examples, Ia. E. Vodarskii, Issledovaniia po istorii russkogo goroda (fakty, obobshcheniia, aspekty) (Moscow: Institut rossiiskoi istorii RAN, 2006); A. B. Kamenskii, Povsednevnost' russkikh gorodskikh obyvatelei: istoricheskie anekdoty iz provintsial'noi zhizni XVIII veka (Moscow: RGGU, 2006); A. I. Kupriianov, Gorodskaia kul'tura russkoi provintsii konets XVII-pervaia polovina XIX veka (Moscow: Novyi khronograf, 2007); George E. Munro, The Most Intentional City: St. Petersburg in the Reign of Catherine the Great (Madison: University of Wisconsin Press, 2008); Alexander M. Martin, Enlightened Metropolis: Constructing Imperial Moscow, 1762-1855 (Oxford: Oxford University Press, 2013). There is also a vast amount of kraevedcheskii material devoted to excavating the past history of individual regions, including towns.

${ }^{11}$ PSZ vol. 19, no. 13468 (May 28, 1770). The reason was probably to aid in transportation between Moscow and St. Petersburg. Vyshnii Volochek and Borovichi were important stops along the water route from Tver' and the Volga to St. Petersburg and the Baltic Sea. Vyshnii Volochek and Valdai were on the road between Moscow and St. Petersburg. Ostashkov, too, was far larger than some towns in the province, though it was not formally
} 
at what was going on. In this decree, part of Novgorod province was broken off and reestablished as a new province centered on a new provincial capital, Olonets. In order to give the new province appropriate administrative centers, two new towns-Vyterga and Padansk-were also established. Furthermore, this law actually spoke to another issue: "about the residents of both the villages themselves and in the districts assigned to them: take those measures that were taken at the time of the founding of new towns before this in Novgorod province." ${ }^{\prime 2}$ In essence, these two laws were the beginnings of the provincial reform promulgated two years later-and they emphasized the fact that towns were central to the process of provincial reorganization. But neither yet quite explained what founding new towns actually meant in a Russian context.

That changed in 1772, however, when Catherine released another decree to the Senate, this one "on the organization of the new-founded towns." 13 In the decree, she approved new physical plans for the new towns and also gave instructions for how those new plans should be put into action. She described and approved coats of arms for the new towns. She established town magistracies, the local bodies given governance over town affairs, as well as assorted district-level offices, and approved grants from the treasury to build stone buildings to house some of these administrations. These concerns were later echoed in the 1775 decree that set up her new guberniia (provincial) administrations. That long law described the many different administrative and judicial bodies that would bring the state to the people, ranging from the governors' offices and treasuries to the "orphans" and "conscience" courts. ${ }^{14}$

There was a second side to the 1772 decree, in particular. Not only did Catherine set out parameters for the physical appearance of towns and for their administration but she also paid far more attention to the lives of the newly created townspeople in them. First and foremost, she stated that those residents who wished to remain in the new towns should take on the social status of townsperson-meshchanin-and should pay taxes appropriate to their new town status. Furthermore, these new townspeople were allowed "to trade and to produce according to the example of other town inhabitants, each to their ability" and in their own homes, not necessarily in specially-constructed merchant rows (rows could be built but were not (yet) mandatory); they could likewise open inns for travelers, with shops to sell prepared foods and provisions for horses (perhaps a reflection of the fact that many of the new towns were important transit stops). Catherine also made provisions for other apparent needs of towns: "supply each town with a grant from the treasury of 300 rubles to open a town school so children may study the Catechism, to read, to write, arithmetic, and to keep merchant accounts."

These two sides represented two different visions of what made a town a town. Towns had clearly long been legally distinct, governed by their own set of laws and statutes. Particularly starting with Catherine (and in many ways starting with Peter the Great's founding of St. Petersburg), they were also meant to be visually distinct. Catherine tasked architects with

classified as one. See Robert E. Jones, Provincial Development in Russia: Catherine II and Jakob Sievers (New Brunswick: Rutgers University Press, 1984), 6o-61, 69, 75.

${ }^{12}$ PSZ vol. 19, no. 14088 (December 20, 1773).

${ }^{13}$ PSZ vol. 19, no. 13780 (April 2, 1772).

${ }^{14}$ PSZ vol. 20, no. 14392 (November 7, 1775). 
creating official plans for her new towns-and for many of the old ones, too. ${ }^{15}$ This visual distinctiveness was put to use, as well, by giving visual order to the range of administrative offices that represented central, regional, and town interests. The second vision focused not on the physical space of towns, but on the people who lived in them. This vision saw towns as spaces inhabited by proper townspeople-merchants and artisans and others producing or building or trading in goods. It saw those proper townspeople as being engaged in their own governance. And it saw them as receiving a proper education that would mark them as different from their village existence. These visions of what a town needed were later reflected almost entirely in the 1785 Charter to the Towns. That charter began with the physical plan of towns, including noting the importance of maintaining appropriate open pastures to support town livestock; it mentioned the importance of schools and public institutions; it described town administration; and it went into great detail about the kinds of townspeople that lived (or ought to live) in towns, working there to make them the productive entities so desired by the central state. Towns were particular physical spaces inhabited by particular people; both were essential to their proper functioning.

These new distinctions between village and town were therefore in the air when Paul received Gatchina as a gift in 1783 . Although Paul as heir had no power to change the legal status of his possessions, he clearly desired to develop Gatchina (and Pavlovsk, granted him several years before) into something distinct from what it had been. As a result, by 1796, when Paul declared the village of Gatchina a town, the region in general and the main village in particular had already undergone a series of changes both in its physical plan and in its population. In most accounts, the changes Paul made to Gatchina symbolized the despotic, tyrannical, Prussian, harsh, militaristic, disciplined side of Paul's character. According to the memoir of Nikolai Sablukov, it was "that terrific place," tying terrific to terror; "the cradle of Paul's army and navy, their organization, institution, drill, and discipline." ${ }^{\prime 6}$ In particular, Paul's actions as the lord of Gatchina during this period have been read by historians as signals of his plans for Russia as a whole. "Over the course of thirteen years he created there in small scale that singular Gatchina-style Russia, which seemed to him to be the only worthy model for the state," wrote one Soviet-era author. ${ }^{17}$ And, according to most, those plans seemed to promise a retrenchment of authoritarianism and serfdom after the hypothetically more enlightened reign of Catherine II. ${ }^{18}$

The transformations that came to the region began with the population. Histories of the town and region described the early eighteenth-century village (myza) as part of the larger world of St. Petersburg, but a peripheral one. In one account, "the village of Gatchina consisted at that time of a few huts, settled by poor Finns, who occupied themselves other than farming with felling wood, cutting stone, burning lime and coal, and also hauling, particularly sand, stone, and wood in the area of Petersburg." ${ }^{\prime 9}$ Even before Paul became the

\footnotetext{
${ }^{15}$ Jones, Provincial Development in Russia, 94-97.

${ }^{16}$ N. A. [Sablukov], "Reminiscences of the Court and Times of the Emperor, Paul I of Russia, Up to the Period of His Death. From the Papers of a Deceased Russian General Officer," Fraser's Magazine for Town and Country 72 (August-September 1865): 222-41, 302-27, here 302.

${ }^{17}$ L. V. Ruzov, Gatchina. Istoricheskii ocherk (Leningrad: Lenizdat, 1959), 14.

${ }^{18}$ A. V. Pomarantskii, Gatchinskii dvorets-muzei i park (Leningrad: Lenizdat, 1939), 6.

${ }^{19}$ Materialy o gorodakh pridvornogo vedomstva. Gorod Gatchino (St. Petersburg: Tipografiia Litografiia dvora
} 
owner of Gatchina, the area began to change. When Grigory Orlov started to build the palace there, he of course required workers to do so, and people came from afar to take part in the construction project. One descendant of some of those initial migrants, the musician, composer, and pedagogue Mikhail Ippolitov-Ivanov, described his family's origins. They were state peasants from Kostroma province, who came to a place settled with "Karelians, Finns, and Estonians, who, living under the constant cultural influence of Livonia and Sweden, carried that culture into the everyday life of the residents of Gatchina." ${ }^{20}$ According to his story, his grandfather, Ivan Matveevich, had come to Gatchina with his wife, two brothers, and his son Mikhail; the men were given special technical training, eventually becoming metalworkers. $^{21}$

Things changed even more when Paul became its owner. For one, more people moved into the area: "retired soldiers and peasants, engaged in small-scale trade in Petersburg and its environs" according to one account. ${ }^{22}$ There was a problem, however. In May 1784, the Senate ordered an ukase be sent to all provincial administrations because of a problem: a "rumor was spreading" that the village of Gatchina was about to be turned into a town, "and that in order to increase the merchants and meshchane there, anyone who just asks will be accepted without examination." Because of this "false rumor," "many household serfs have run away in the belief that they will become citizens." The decree did not flat out state that the village would not become a town, but it did emphasize that runaways and fugitives and those without passports would be dealt with according to the laws (which meant arrest and return), not allowed to stay. ${ }^{23}$ In principle, the Grand Duke took "decisive measures against the appearance in the environs of Gatchina of vagrants and people without passports." ${ }^{24}$ In practice, though, Paul's plans to rebuild Gatchina may have made it necessary to look the other way when it came to illicit mobility. ${ }^{25}$

Changing the physical structure of Gatchina and its region was the second transformation of Paul's tenure as its owner. Many of Paul's building projects had to do with fortifying his domain against outside attack - this part, in particular, has been read as an example of his paranoia, above all. First of all came barracks near every entrance to the palace complex itself - "so that the former village obtained the look of a permanent military encampment." 6 But Paul also began to change, or at least to plan to change, the physical structure of the village in ways that aimed to improve the lives of its residents-and in ways that already introduced institutions associated with towns. A hospital and a school (uchilishche) made the village a draw for the wider population of the region, emphasizing that it was first among

\footnotetext{
ego imperatorskogo velichestva, 1882), 1-2.

${ }^{20}$ M. M. Ippolitov-Ivanov, 50 let russkoi muzyki v moikh vospominaniiakh (Moscow: Gosudarstvennoe muzykal'noe izdatel'stvo, 1934), 5. A later history also notes that state peasants from Kostroma and Vologda provinces were brought in to work on the palace. Ruzov and Iablochkin, Gatchina, 10.

${ }^{21}$ Ippolitov-Ivanov, 50 let, 6.

${ }^{22}$ Materialy, 4.

${ }^{23}$ PSZ vol. 22, no. 15997 (May 17 1784).

${ }^{24}$ Stoletie, 6.

${ }^{25}$ Alison K. Smith, "False Passports, Undocumented Workers, and Public (Dis)Order in Late-EighteenthCentury Russia," Journal of Social History (Spring 2020): 1-21.

${ }^{26}$ Stoletie, 8.
} 
many local villages. ${ }^{27}$ One later history of the region described Paul's new plan for the village as made necessary by the increase in population. ${ }^{28}$ Much of it, though, aimed at its original population-a Lutheran church for the Finnish population, for example, and a school to go with it. ${ }^{29}$ And there was yet another layer: improvements intended to make the village into a thriving economic concern. According to the official centenary history of the town, Paul gave manufacturers grants of land and loans to get their businesses started; as a result, Gatchina became home to factories producing glass, porcelain, and textiles. ${ }^{30}$

Paul was also interested in governance. In a series of regulatory documents compiled in 1793-a nakaz, an instruktsiia, a reglament, an ustav-he outlined oversight over construction work on the larger Gatchina estate, rules for keeping order between troops quartered on the estate and their civilian hosts, and rules for night watchmen to keep the public peace (and to keep the streets clean). ${ }^{31}$ In one, dated November 19, 1793, Paul established rules for policing Gatchina proper. The document began: "We have seen that many people of various statuses have expressed their wish to settle, build, and conduct their business in the area of our suburban Gatchina palace." ${ }^{2}$ Paul was recognizing the changing (and growing) population, and also the need to establish rules for the proper functioning of Gatchina's society. There are other things here. He referred not to his village (myza) of Gatchina, but instead of the "Gatchina palace posad." And he wrote of the inhabitants of this posad in ways that turned it into a proper town in all but name: it granted the "respectable" (dobroporiadochnye) residents their homes with a plot of land, and stated that they should be "noted in the number of residents of the posad, granting them the right to ply manufactures, trades, and to become contractors." According to the official centenary history of the town, this was an important moment because it created two classes distinct in their economic and, in principle, at least, their moral character. ${ }^{33}$

All of these acts had begun to differentiate the village of Gatchina proper from the larger palace estate. Once Paul came to the throne, he immediately moved to formalize this difference. "Our own village of Gatchina," he decreed, "having been renamed a town, we command its administration with the district belonging to it remain on that very basis that up until now under Our ownership was founded." 34 This meant he drew on the existing structures established in his various orders and instructions, making them the basis of the new town's structures. Two weeks later, Paul released another decree, stating that the town was to have direct access to the Senate, should any need arise. ${ }^{35}$ And then in early January, yet another decree set out the parameters of the new town's administration. ${ }^{36}$ The new Gatchina Town Administration (Gatchinskoe gorodovoe pravlenie) was to be headed by an overseer (Glavnoupravliaiushchii), and divided into two parts, one to handle everyday

\footnotetext{
${ }^{27}$ Stoletie, 11-12.

${ }^{28}$ Materialy, 4.

${ }^{29}$ Stoletie, 8-9.

${ }^{30}$ Stoletie, 13.

${ }^{31}$ Stoletie, 16-22.

${ }^{32}$ Stoletie, 23.

${ }^{33}$ Stoletie, 23.

${ }^{34}$ PSZ vol. 24, no. 17539 (November 11, 1796).

${ }^{3}$ PSZ vol. 24, no. 17578 (November 24, 1796).

${ }^{36}$ PSZ vol. 24, no. 17725 (January 12, 1797, published January 30).
} 
management, one to handle finances and accounts. The administration had oversight over the new town of Gatchina, the palace and its grounds, and the villages that belonged to the larger palace estate. The town had its own Kommendant, and each of its four sections was to have a Chastnyi kommisar. In addition, the people of the town-the merchants, artisans, and meshchane-were to be represented by a town council, a ratusha. Paul followed the decree setting up the administration and listing all its employees with another decree stating that its cost (a total sum of 26,181 rubles 48 kopeks per year) was to be paid for from the treasury. ${ }^{37}$

These decrees gave an administrative structure to the new town that was distinctly different than that of the towns founded by Catherine in large part because of the existence of the Gatchina Town Administration. It became the coordinating body for virtually everything to do not only with life in the town but also with life in the palace and in the neighboring villages. It received directives from the Senate and from the Main Administrator appointed by Paul, Petr Khrisanfovich Obol'ianinov, who lived primarily in St. Petersburg but who at times also corresponded with the Administration from Tsarskoe Selo or even from Gatchina palace itself, receiving daily reports and sending daily directives. He played an active role in the administration of the region, receiving and responding not only to reports from the Gatchina Town Administration but also to petitions from individuals. ${ }^{38}$

The Gatchina Town Administration, however, handled the day to day operation of the palace, the town, and the villages in the area. According to its journals, which begin in March 1797, the Administration offices opened for business at 8 in the morning five or six days a week, and closed for the day at 2:00 $\mathrm{pm} .{ }^{39}$ Each day some subset of the town administration's chinovniki sat down to deal with incoming letters and to deal in person with those who stopped into the office. On December 1, 1798, an average Wednesday, two men were on duty: a sovetnik, Collegiate Councillor Romanovskii, and an assesor, Court Councilor Starov. ${ }^{40}$

On this average day, they recorded incoming decrees from the Governing Senate, in this case one on the process for submitting appeals and one announcing a search for a fugitive merchant. The decrees are copied out in the journals and followed by a statement of the Administration's actions in response to the decrees: in this case, to send back notices of having received the decrees. Next were two orders from Obol'ianinov. One dealt with a contractor who had agreed to supply the palace with firewood, the other on the situation created when Gatchina was made a town and a nearby town, Rozhdestveno, had that status revoked. At that time, the merchants and townspeople of the former town of Rozhdestveno were allowed to register in Gatchina, a practice that caused problems in part because they largely continued to live in the former town.

Obol'ianinov's orders were followed by a series of notices from other regional authorities. There were notices from provincial administrations, from provincial treasury departments, and from St. Petersburg provincial or town authorities. They were often seeking people who

\footnotetext{
${ }^{37}$ PSZ vol. 24, no. 17726 (January 12, 1797). A list of all the positions plus their salaries is at Rossiiskii gosudarstvennyi istoricheskii arkhiv (henceforth RGIA) f. 491, op. 1, d. 8 o.

${ }_{38}^{8}$ RGIA f. 491, op. 1, d. 31.

39 The Gatchina Town Administration officially began operations slightly earlier, on January 24, 1797, but the journals still in the archives begin in March. On its official opening, see Stoletie, 6o.

${ }^{40}$ RGIA f. 491 op. 5, d. 295, 1. 10 .
} 
had run away or who were needed for some legal matter. Or they were disseminating information about new markets. These sorts of notices were distributed to the police for publication. Next came reports from other parts of the larger Gatchina administration. There were four reports from the economic office (that is, reports having to do with finances); a report from the former Rozhdestvo town ratusha on the process of transferring its merchants and townspeople to registry in Gatchina; reports from Vasilii Tokmachev, the overseer of the Deer Park and forests, from Egor' Shpitsberg, the police chief, and from Gustav Dordet, one of the rural police officials. There were reports from the overseers of the palace stores on giving out various thing, from the palace masonry master Visconti on an issue with building a wall, and from the tavern keeper Shtraus on recent sales and passing on the required cut to the palace treasury.

On that day the Gatchina Town Administration also dealt with a series of requests and petitions. They included petitions from a newly registered meshchanin about his dues; from four Vologda peasants who wanted passes to live in Petersburg for 3 months (according to investigation, they had requested to register in the Gatchina meshchanstvo; their requests were awaiting approval from Vologda so they had been living on a residence certificate from the Gatchina Town Administration; the request for new passes was granted); from a Novgorod iamshchik who had an even more complicated current status but who was also granted an eight-day travel pass; from an Arkhangel'sk peasant seeking a pass to St. Petersburg (in his case, because of additional complications with his status, he was not granted such a pass and instead given one to go back to Arkhangel'sk); and from another Vologda peasant looking for a St. Petersburg pass (he, too, was just given a pass back to Vologda).

On this particular day, only one person came into the office to do business in person: a peasant wanting to take on a contract to do some work. But on other days, many other kinds of matters were dealt with face to face. On December 2, for example, two peasant women from the larger Gatchina estate came into the office to request year-long passports to go to St. Petersburg for work. The Gatchina Town Administration granted their request. ${ }^{41}$ The police gave reports orally; the builders and gardeners came in to deal with work or payment issues. Finally, the daily journal ends with a statement of items that had been resolved and reported on. At this point, most of these cases were of people looking to become Gatchina merchants and meshchane-cases that speak to one of the other major background issues of the new town, establishing its population properly.

The massive amounts of construction initiated under Paul's regime required people. There were foreign specialists, like the Swiss-Italian stone working master Placido Visconti, who in 1798 had the highest salary of any of the people working for the palace (tied with the [also foreign] garden master). Two years later, when he asked for permission to leave service in Russia to return home with his wife Marianna Casagrande and son, he was given 1000 rubles as a reward for his service. ${ }^{42}$ Unlike some of the other foreign specialists in the area, Visconti often signed his name in very serviceable Cyrillic characters, something that is

\footnotetext{
${ }^{41}$ Ibid., 1. 27ob.

${ }^{42}$ RGIA f. 491, op. 5, d. 153, 1l. 87, 94. For more on Visconti, see Nicola Navone, Bâtir pour les tsars: architectes tessinois en Russie, 1700-1850, trans. Etienne Barilier (Lausanne: PPUR, 2007), 52.
} 
recorded because he signed many, many agreements with contractors to do work around the palace grounds. Those contractors are the second group of people involved in the construction work in the area. They were sometimes merchants in the new town, but often state (or other) peasants living in the area on passports. The third group are the actual construction workers themselves. They were occasionally locals, but usually, it seems, more state peasants or serfs who flocked to the region either on passports or without them (in that case, they often ended up pulled in for questioning because of their undocumented status). ${ }^{43}$

Different elements of the local administration dealt with these different elements of the local society. In principle, throughout the Russian empire in the eighteenth century, town populations were overseen and governed on a local level by elected councils known as the magistrat or the ratusha. As Paul decreed, when it became a town Gatchina needed one of these, as well-although here, the new ratusha would work in parallel to the Gatchina Town Administration. In March of 1797, the Gatchina Town Administration took action to make sure that the ratusha demanded by Paul's decree be established. Elections were held for positions within the ratusha, and a decree formally opening the ratusha was signed on April 28, $1797 .{ }^{44}$ The ratusha dealt above all with questions involving the Gatchina business community. Already by the end of 1797 , it had decided at least two cases involving difficulties in collecting payments and fulfilling contracts. ${ }^{45}$ In 1798 , the ratusha was meeting and issuing decisions on many different cases: someone already wanting to be released from membership in the Gatchina town society, a question about liquor sales in the town, a wage dispute, the case of a woman's assault. ${ }^{46}$

In principle, the ratusha above all oversaw another important part of town governance: the registry of new merchants and meshchane. Throughout the eighteenth century, this had been one of the major roles of town ratushi and magistraty. In Gatchina, however, at least in these first years of Paul's reign and the new town's existence as a town, this authority was complicated by the sheer scale of mobility, licit and illicit, in the area. The new town attracted new people immediately, even before its formal structures were set up. Paul declared the new town to be on November 11, 1796. The Gatchina Town Administration was not set up until January 1797, and the ratusha not until April. But already by the end of December 1796, people were showing up to register. In one case, a man named Dorofei Alekseev Zgibnev showed up in Gatchina with a year-long passport from Bronnitsy district, asking to register in Gatchina as a third guild merchant along with his brother Semën and family. ${ }^{47}$ This of course created a huge question for local authorities, who were not even formally constituted yet.

As a result, the new administrative bodies had first of all to figure out what and who they were administering. Already on May 6, 1797, the ratusha made a request of the Gatchina Town Administration: they asked for a list of all the people who had registered as merchants in Gatchina so they could make an alphabetical list for their own records. The Gatchina Town

\footnotetext{
${ }^{43}$ See Smith, "False Passports, Undocumented Workers, and Public (Dis)Order."

${ }^{44}$ Tsentral'nyi gosudarstvennyi istoricheskii arkhiv Sankt-Peterburga (henceforth TsGIA SPb) f. 1708, op. 1, d. 1, 1. 4 .

${ }^{45}$ TsGIA SPb f. 1708, op. 1, d. 136. (There were probably more, but these two have survived.)

${ }^{46}$ TsGIA SPb f. 1708, op. 1, d. 6.

${ }^{47}$ RGIA f. 491, op.1, d. 28, 1. 1.
} 
Administration, however, was as in the dark as the ratusha about this. Furthermore, the Gatchina Town Administration's records note, "even several members of this ratusha have not yet been excluded from the provinces in which they were formerly registered" in order to become proper Gatchinites. The Gatchina Town Administration was therefore unable to fulfill the ratusha's request. ${ }^{48}$ In other words, even as Paul's decrees founded institutions proper to towns, what that meant in terms of actual population was still unclear.

Paul's acts while still Grand Duke are important for figuring out what was going on with the local population, in particular his recognition of the "respectable" residents of Gatchina and their trade. It is a bit unclear from the archives, but this category of "respectable" Gatchinites seem to have been the first official townspeople, out of whose ranks came most of the members of the first ratusha. But as the correspondence between the ratusha and the Gatchina Town Administration shows, not all were. Soon, however, the Gatchina ratusha began to register individual merchants and meshchane in the town. On May 17, 1797, three men became the first new meshchane of Gatchina: Sëmen Sokolov and Anton Dubrovskii, both already meshchane from Polotsk, and Fedor Pirogov, an economic peasant (that is, a peasant from a village that had been initially owned by a monastery but which was confiscated by the state at the beginning of Catherine's reign) from Kostroma province. ${ }^{49} \mathrm{~A}$ few days later, on May 21, three men became the first new merchants: Egor and Khristian Gelembolt, both described as "foreigners" from Riga, and Martyn Zegebart, a "foreigner" from Prussia. ${ }^{50}$ By the end of 1798, twenty-eight new merchants and seventy-two new meshchane and artisans had registered. Because some had entered along with their families, that meant a total of fifty-two merchants and 110 meshchane and artisans. ${ }^{11}$ By 1800 , the numbers had grown even more: a total of 95 souls listed as merchants, and 288 artisans and meshchane..$^{2}$

These numbers, however, belie the scale of what was going on in Gatchina during these years. A better sense of what was going on comes from a proposal made by Obol'ianinov, sent to the new Gatchina Town Administration on January 22, 1797. In it, he stated that "in order to maintain necessary order and proper registry," the Gatchina Town Administration was to investigate all those who had shown up to register in Gatchina "spontaneously" (samoproizvol'no). The Gatchina Town Administration (not the ratusha, interestingly) was to find out where everyone who declared a wish to register in Gatchina was legally registered and then to write to their provincial administrations to check up on whether those people were indeed already registered in those provinces, whether they were of good behavior, and whether their home societies were willing to free them to become Gatchina merchants and meshchane. If their prior status could be verified and their official status change agreed to by all, they were to be registered in Gatchina, as well..$^{33}$

Obol'ianinov's order was a disruption of the normal rules of registration. Nor was it the first time he had made such a declaration. In 1796, Obol'ianinov wrote to provincial

\footnotetext{
${ }^{48}$ RGIA f. 491, op. 5, d. 278, 1l. 150b-16.

${ }^{49}$ RGIA f. 491, op. 1, d. 315, 1. 8 b.

${ }^{50}$ RGIA f. 491, op. 1, d. 315, 1. 8a; d. 182, 1. 2.

${ }^{51}$ RGIA f. 491, op. 1, d. 315.

${ }^{52}$ RGIA f. 491, op. 1, d. 317, 1. 25. These numbers include only male souls; women were not yet counted.

53 RGIA f. 491, op. 1, d 28, 1. 2.
} 
authorities asking that renewed passports be sent to people currently living in Gatchina; at this point, there was no official decree allowing such renewal in absentia, nor would there be one until 1798, although evidence from Gatchina clearly shows that many people did so. ${ }^{54}$ By this point, there was a standard process by which individuals could change their official soslovie status and place of registry. They needed to show both formal release from their home society and also acceptance from their new society. Normally, an individual was supposed to show up for registry with both of these documents in hand. Obol'ianinov's order implied that many of those showing up for registry in Gatchina did not already have those documents-hence the need for further investigation. And it also stated that this irregular behavior could be overlooked in Gatchina-it allowed a kind of mobility outside the normal bounds of the laws, presumably because the goal of establishing the new town as an active and growing center was deemed important enough to allow for it.

As a result, the Gatchina Town Administration eventually wrote to twenty-three separate provinces to confirm the status of men wishing to register in Gatchina. ${ }^{55}$ In some cases, there were only one or two would-be Gatchinites, but overall the numbers were significant. For example, the Gatchina authorities inquired about 283 separate individuals from Vologda province asking for registry (this was probably the largest number of would-be registrants from any one province; many also came from Novgorod province). ${ }^{56}$

Provinces eventually responded with detailed information about the applicants for Gatchina status. They reported on where the men appeared on the tax census lists, and on whether their home villages (in the cases of state peasants, most of the applicants) were willing to free the men from their local responsibilities. Some had straightforward cases in which villages reported that the men had left home with passports and that they were furthermore willing to free them. ${ }^{57}$ Others, however, been listed as runaways as of the last (fifth) census held in 1796. Vasilii Zhgilev and Andrei Kopylov were both listed as runaways by their home villages in Vologda province. Larion Belykh had more detailed informationhe had left home in 1789 with a valid two-year passport, but had not returned since. Their home villages responded to this in different ways. In principle, the runaways were no longer on the tax rolls, and so were now without registration and therefore open to registry somewhere new. This was the tack taken in some cases. Zhgilev, for example, was simply freed by his society. ${ }^{58}$ Kopylov's home village, however, wanted to get him back on their own register, "because he is useful for the commune's requirements" (another document stated their reasons differently: "his father and uncle are old, and they are not able to pay taxes for

\footnotetext{
${ }^{54}$ On Obol'ianinov's request and responses, RGIA f. 491, op. 1, d. 133. On the 1798 decree and its importance, see V. G. Chernukha, Pasport v Rossii, 1719-1917 gg. (St. Petersburg: Liki Rossii, 2007), 50-51. On evidence of the practice of renewing passports in absentia well before 1798, see Smith, "False Passports, Undocumented Workers, and Public (Dis)Order."

${ }^{55}$ RGIA f. 491, op. 1, dd. 103-125.

${ }^{56}$ The file for Vologda is d. 104, for Novgorod is d. 112.

${ }^{57}$ For example, Vasilii Lebedev, RGIA f. 491, op. 1, d. 104, 1. 130ob.

${ }^{58}$ Ibid., 1. 107.
} 
him"). ${ }^{59}$ And Belykh's village stated that they were unable to free him formally because they did not know where he was. ${ }^{60}$

This also created all sorts of complications for the Gatchina authorities. For example, in December 1796, Vasilii Gerasimov Bulkin showed up in Gatchina asking to register as a meshchanin. He had with him a passport from his home district (Valdai) in Novgorod province. On February 8, 1797, the Gatchina Town Administration wrote to Novgorod province about him in order to regularize his status. In April, he, like many of the other petitioners, received a temporary residency permit for Gatchina due to the fact that his passport had expired. On August 8, 1797, the Novgorod authorities reported back on his status: his village was willing to allow him to transfer his registry to Gatchina, but only if he paid them 20 rubles (the rationale was that the village supported the postal (iam) system, and therefore needed the money to be sure that they were prepared for when the Emperor traveled along the road between Moscow and St. Petersburg). The case seems to have held up there for a while, as more than a year later, on December 1, 1798, Bulkin, still describing himself as a Novgorod peasant, asked for a three-month residency permit for St. Petersburg. He claimed that he would be able to get those 20 rubles demanded by his home village within a week if he was allowed to go to Petersburg, and so the Gatchina authorities allowed him to leave. ${ }^{61}$ He must have been successful, as a later register of newly registered Gatchina merchants and meshchane lists him as having become a meshchanin in $1798 .{ }^{62}$ He apparently also must have kept asking for residency permits for St. Petersburg, for in another register from 1801, he is listed as married to a peasant daughter from Vologda province named Akulina Grigor'eva and living St. Petersburg, working as a marble worker (which hints at the job that may have brought him to Gatchina in the first place). ${ }^{63}$

All of this effort to regularize the status of these men, however, reads rather like a futile effort to hold back a flood. For one thing, a lot of this effort does not seem to have ended up developing the actual registered population of Gatchina. Few of the men listed above show up on residency lists from 1801-05 (nor do a few others who were also freed from their villages without a problem). ${ }^{64}$ In some cases, people simply disappeared after making their requests to join the society. In February 1800, the Ratusha reported to the Gatchina Town Administration that six people who had been granted registry in Gatchina had not shown up to finalize that registration; they were therefore asking that the Gatchina Town Administration send notice to St. Petersburg to inquire as to whether the men were living there. ${ }^{65}$ In another case, an economic peasant from Moscow province named Ivan Zaverniaev requested registry in 1797, receiving at that time a living permit because his passport expired that year. In October 1798, Moscow authorities reported back that his village was willing to free him-but in the intervening months he had gone off somewhere and never reappeared to finalize his registry. He did eventually show up again in the records in late 1799. At that

\footnotetext{
59 Ibid., l. 130; d. 133, 1. 130.

${ }^{60}$ RGIA f. 491, op. 1, d. 104, 1. 126ob.

${ }^{61}$ RGIA f. 491, op. 5, d. 295, 1l. 10-10ob.

${ }^{62}$ RGIA f. 491, op. 1, d. 182, 1. 11.

${ }^{6} 3$ TsGIA SPb f. 1708, op. 1, d. 47 .

64 TsGIA SPb f. 1708, op. 1, dd. 47, 103.

${ }^{65}$ RGIA f. 491, op. 5, d. 308, 1. 206ob.
} 
point, he had submitted a petition to Emperor Paul himself, in which he claimed the identity of a Gatchina meshchanin and asked for "monarchical mercy in his poverty." At this point, however, the Gatchina ratusha reported that they were now unwilling to accept him into the meshchanin ranks even if he showed up to finalize his registry "due to the weakness of his health, his unknown behavior, and the unlikelihood that he will pay his taxes properly."

Given that a large number of the men asking for registry were described as having run away from their former status, they might not have been after actual registry in a new place, but instead were looking for a new transitional status. The men who had applied for Gatchina status were given temporary residency tickets to regularize their place while their status was checked into more formally. This allowed some of them, at least, to claim a place within the larger society, at least for a while. Some, though, continued to find themselves in trouble with the law for their failure to live according to the laws of registration. In April and May of 1797, for example, the St. Petersburg police arrested two men for drunken fightingFedor Zhilin and Parfentii Pankrat'ev. Both men claimed to be Gatchina meshchane. However, as it turned out, both were actually peasants who had requested registration in Gatchina but whose files were not yet complete. Their bad behavior got them pushed outZhilin was beaten with rods, and because Pankrat'ev was known to lead a "dissolute life," he was preemptively excluded from the Gatchina meshchanin lists. ${ }^{67}$

In addition, many people who had requested registry but not yet completed the process showed up on lists of people arrested for working or living in the area without legal documents. Between November 1797 and August 1798, Gatchina police authorities arrested and questioned at least 225 people, nearly all men, for working in or traveling through the area without proper documents giving them permission to do so. ${ }^{68} \mathrm{~A}$ few admitted to being fugitives pure and simple-Mikhail Filatov, a serf from Tver' province, stated that in 1794 he ran away "from the great obrok and barshchina levied on him." ${ }^{69}$ But many claimed to have had proper papers at some point in the past, but either to have lost them or to have let them expire. In some cases these were passports from their home districts, but there was also a large number of men who had requested registry in Gatchina and received temporary permits - but those, too, had started to expire by 1798.

The presence of so many fugitives and undocumented people, along with the wasted work of following up on would-be registrants when some failed to reappear or to behave properly, may well be what led Obol'ianinov to send a new directive in January 1798. According to this policy, "from now on those who wish to register in the Gatchina merchant or meshchanin estate are required to ask their komanda [for permission to leave] directly." The Senate itself was to decide whether to register or refuse the would-be Gatchina townspeople. And anyone living and working in Gatchina must "without exception" have a passport from their home

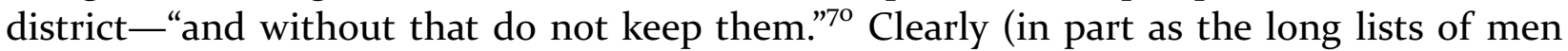
arrested for not having documents shows), this was easier said than done, for Obol'ianinov repeated the demand the following year: "all meshchane and peasants not registered in the

${ }^{66}$ RGIA f. 491, op. 5, d. 307, 11. 87-87ob; d. 308, 11. 120-12ob.

${ }^{67}$ RGIA f. 491, op. 5, d. 277, 1l. 27ob-28 and d. 278, 11. 39ob-40.

${ }^{68}$ RGIA f. 491, op. 1, dd. 98, 228, 233, 238.

${ }^{69}$ RGIA f. 491, op. 1, d. $238,1.43$.

${ }^{70}$ RGIA f. 491, op. 5, d. 284, l. 32 ob. 
Gatchina merchant and meshchanin estates and not having from those places under whose authority they belong passports, return them to their former residences." ${ }^{71}$

These were not surprising statements; in fact, if anything, they were a restatement of official policy about the need for documents. In this way, they demonstrate that the period in which the transformation of Gatchina the village into Gatchina the town allowed an unusual degree of mobility was at an end. This might indicate that the town had been, in the eyes of the authorities, well enough established that it no longer needed its own special, looser rules. Or it might mean that the scale of undocumented workers that this policy helped to create was deemed too much a security threat to continue.

There were many problems with the process of listing and labeling the population of the new town of Gatchina, but the process did eventually lead to the better establishment of the town proper. By May 1798, Gatchina was small but bustling. There were twenty-four small shops, most of them melochnye lavki. A Gatchina merchant named Gerasim Alekseev Balin ran a liquor store (renskii pogreb). Several market gardens also supplied the town with produce. ${ }^{72}$ The several hundred new merchants and townspeople of Gatchina gave it a basis to continue to grow and develop, though it would remain small for decades after. (This was particularly true after Paul's death, when Gatchina lost place. Eventually, in 1811, a decree liquidated the Gatchina and Pavlovsk ratushi; the towns still had merchants and meshchane, but now they were registered via the Tsarskoe Selo assembly. ${ }^{73}$ In principle, the change was made because of the small number of merchants and meshchane in the two towns; in practice, it seemed to reduce the importance and independence of the town in comparison with the palace.)

This movement of people also accomplished something else: it created a distinctly Russian town (if a Russian town that reminded everyone who visited it of Prussia) in a larger non-Russian space. Most of the villagers in the area were Finns. But nearly all the men arrested in Gatchina for being without documents were from Great Russian provinces and bore Russian names, and nearly all of the new merchants, artisans, and meshchane of Gatchina were from Great Russian provinces or Germans (and in a way, having German artisans and merchants in it was perhaps as much a marker of Russian-town-ness as anything).

For example, according to one list, in 1797 fifteen new merchants registered in the town. Four of them were already merchants, one from Tver', one from Uglich, and two from Viaz'ma. One was a meshchanin from Gzhatsk, one a iamshchik from Novgorod. All but two of the remaining new merchants were foreigners. The following year, another thirteen new merchants joined them. This time, only one was a foreigner; three were merchants, from Rostov, Viaz'ma, and Toropets; two were townspeople from Kashin and St. Petersburg; and the remainder peasants, from Kostroma, Iaroslavl', Arkhangel'sk, and Vladimir provinces. ${ }^{74}$ The only exceptions (perhaps/probably) were two new merchants from the Gatchina estate village of Kolpino: Il'ia Nudin, who became a second guild merchant, and Abram Kuivane,

\footnotetext{
${ }^{71}$ RGIA f. 491, op. 5, d. 310, 1l. 104ob-05.

${ }^{72}$ TsGIA SPb f. 1708, op. 1, d. 7, 1. 10.

${ }^{73}$ Stoletie, 71.

${ }^{74}$ RGIA f. 491, op. 1, d. 315, 11. 11-11ob, 8b-10. 12-13.
} 
who became a third guild merchant, both in June $1797 .{ }^{75}$ This may have been an additional reason for the reduced scrutiny - or not reduced scrutiny, but increased methods of getting registered-in Gatchina: more firmly establishing the Russian presence in this borderland area. Therefore, in this space at least, the new town became an institution of the multinational empire as much as of the autocratic one.

${ }^{75}$ RGIA f. 491, op. 1, d. 315, 11. 8a-8a ob; d. 182, 11. 1ob-2. When Kuivane was elected to be the town starosta in 1799, the local police chief, Shpitsberg, was very upset. TsGIA SPb f. 1798, op. 1, d. 27, esp. 11. 19-20. 